\title{
Community Health Centres: An Innovative Approach to Newcomer Settlement Services
}

\author{
Janet McLellan
}

\begin{abstract}
While NGO settlement agencies face increasing challenges to deliver bath ethnospecific and larger broad-based programs for immigrants and refugees, Community Health Centres (CHCs) in large urban areas of Ontario have developed innovative means to meet the health and settlement needs of newcomers. Positive mental and physical health through access to medical and social resources, recognition of health determinants and enhanced participation in decision making are integral elements of CHC settlement and integration programs and services, all within the context of medical care. Through extensive outreach programs to newcomer communities, CHCs enhance the effectiveness of ethnospecific groups to define culturally appropriate services. CHCs provide an example of desired social change through a mainstream institutional basis.
\end{abstract}

\section{Précis}

Dans un contexte où les ONG jouant le rôle d'agences d'intégration font face d̀ des défis croissants dans l'exécution de leurs tâches d'organisation des programmes "ethno-spécifiques" ou "généraux" pour immigrants et réfugiés, les Centres de Santé Communautaire (Community Health Centres, abrégé ici en (SC) opérant dans les vastes agglomérations urbaines de l'Ontario ont développé des façons de faire novatrices pour rencontrer les besoins en soins de santé et en intégration générale des nouveaux arrivants. Une approche positive de la santé physique et de la santé mentale via l'accessibilité aux ressources médicales et sociales, la reconnaissance des facteurs détermi-

Janet McLellan, PhD, is Assistant Professor, Department for the Study of Religion, University of Toronto, Toronto. nants en matière de santé, et une participation accrue aux différents processus décisionnels sont autant d'éléments constitutifs des programmes et des services d'intégration organisés par les CSC, dans un strict contexte de soins médicaux. Par l'action systématique de programmes de sensibilisation des communautés de nouveaux arrivants à leurs droits, les CSC augmentent nettement l'efficacité des groupes "ethnospécifiques" dans leur action visant à définir des services culturellement adéquats. Les CSC constituent un exemple. de changements sociaux allant dans la bonne direction tout en s'articulant sur la base d'une instance institutionnelle "classique".

For over two decades, various levels of government funding in Canada have provided an array of services, both directly and indirectly, to newcomers early upon their arrival. ${ }^{1}$ Settlement services are available to officially landed immigrants or refugees. Asylum or refugee claimants are not eligible, except for medical coverage. Settlement services provide a social "safety net," even though their programs may be impersonally administered. In large settlement agencies, services tend to be delivered on a categorical basis depending on the qualifications of the entering newcomers, rather than upon their recent experiences. The Cohort Qualification Model, characteristic of most Western countries of resettlement, provides fixed sets of services at different periods after arrival, and is premised on the assumption that newcomers go through a process that includes language skills acquisition, redevelopment of psychological well-being and finançial stabilization, all of which will decrease dependence on front-line settlement as the length of stay and adaptation increase (Lanphier, McLellan and Opoku-Dapaah 1995). The liabilities of this system, however, include problems of newcomers fitting service parameters, which may not be culturally appropriate or sensitive, especially to refugees.

In present-day Ontario, increasing restrictions of government grants, cutbacks in public sector funding and generalized recessionary cost-cutting measures are threatening the capacity of settlement agencies to deliver both ethnospecific and larger broad-based programs. ${ }^{2}$ Continuing restrictions on settlement funding adds to an escalating competition among settlement agencies to access limited government support. Within particular ethnospecific newcomer communities, several agencies may exist to provide orientation and settlement services, each claiming authenticity and unique expertise in addressing and meeting the particular needs of their members. Very few newcomer communities are homogenous, and most have numerous smaller sub-groupings differentiated by ethnic, political, class or religious differences. In Toronto, for example, over fifty-five organizations have been created within the last few years to serve African refugees, with over twenty-two of these organizations oriented to the Somali community alone (Opoku-Dapaah 1993). Not only do personnel with the ethnic communities become thinly spread organizationally, but government and other community agencies can also become confused and cynical by what appears to be excessive overlapping of multiple ethnospecific services (Lanphier, McLellan, and Opoku-Dapaah 1995).

Despite governmental guidelines for what constitutes settlement services, there is little verification if programs are being implemented within ethnospecific agencies, their effectiveness or degree of community partici- 
pation. Overall emphasis remains focused on short term needs such as orientation and immediate settlement assistance. Incipient barriers to long term social participation (such as lack of communication or employment skills, extensive family and community breakdown or post-traumatic stress disorders) are frequently not acted upon effectively, leading to extensive adaptive and integrative difficulties, a situation demonstrated by McLellan (1995) with respect to Cambodian refugees.

In contrast to the universalistic Cohort Qualification Model of most settlement agencies, several Community Health Centres (CHCs) in Ontario have developed distinctive outreach approaches to immigrant and refugee communities that acknowledge and address particularistic needs. ${ }^{3}$ As an extension of the mainstream institutionalized health care system, $\mathrm{CHCs}$ provide innovative avenues through which specific ethno-religious groups access available health services in culturally appropriate ways. In the attempt to help newcomers overcome linguistic, cultural and racial barriers, thereby fostering adaptive success and integration into other mainstream services and resources, $\mathrm{CHCs}$ are playing an increasingly crucial, but still little publicized, role in the process of newcomer settlement.

\section{The Community Health Centre Approach to Newcomer Settlement Services}

Thousands of immigrants and refugees have settled in the neighbourhoods served by $\mathrm{CHCs}$, especially in the larger urban areas such as Toronto, Ottawa, London and Sudbury. Their representative participation on the CHC boards has been essential in the planning process of programs and services to meet specific needs. The range of coordinated primary health care and related social services available at $\mathrm{CHCs}$ are provided in a multidisciplinary manner. Individual case management within the $\mathrm{CHC}$ is also integrated within a broader community based network of health and so- cial service systems. CHCs can exist independently or be part of a larger service component which may provide health, social, housing, legal and other related services.

In addition to global program funding from the Ministry of Health, $\mathrm{CHCs}$ receive time-limited grants from other provincial ministries (those that deal with community and social service and skills development), Health and Welfare Canada, municipal and regional jurisdictions, the United Way, Ontario Legal Aid Society and private donations. The pluralistic approach to funding (core and annual grants) enables a flexible program implementation that allows the hiring of a variety of health and social service care professionals such as doctors, nurses, chiropodists, workers seconded from other mainstream agencies, health promoters/educators, nurse practitioners, translators, community outreach workers, social workers, nutrition counsellors and ethnospecific traditional medical healers. The multidisciplinary team ensures that clients have access to a variety of services to meet their needs, that through consultation with individuals or a group the team can develop an appropriate care plan, and that internal referrals are easily made with access to the appropriate service provider on-site or with an external agency such as the Children's Aid (Ministry of Health 1993a). A patient may see more than one provider during a single visit to a $\mathrm{CHC}$, whereas in fee-for-service health care provision these multiple encounters would be billed separately (ARA 1992). Ontario Hospital Insurance Plan (OHIP) numbers are used at $\mathrm{CHCs}$, but for those without (homeless people, illegals or "non-insured refugees or refugee claimants"), the Provincial Ministry of Health has given extra funding (beyond the base budget) which covers all primary care services as well as consultation with specialists, lab work, X-rays and ultra sound.

Primary care services and health promotion programs at $\mathrm{CHCs}$ are directed towards priority populations who may require better access to care and/or who have a higher disease burden requiring additional resources. Barriers to accessing health care may be the result of numerous factors (such as socioeconomic status, geographic isolation or linguistic and literacy difficulties) and the illness burden may be related to age, socioeconomic status, recent history (such as refugee camp conditions) or environmental factors. Contrary to the prevailing distinctions between newcomer settlement needs (immigrants, refugees and refugee claimants) and the needs of those born in Canada or those with long term residency, the CHC philosophy is to provide community-based services to all individuals without categorical discrimination. According to Richmond (1994, 17) terms such as "immigrant," "refugee," "refugee claimant" and "visible minority" are symbolic signifiers that categorize people according to particular criteria that, in turn, convey complex sets of meaning according to the historical context and specific situations. As Wong (1989) notes, classification of people often controls and facilitates techniques of administration and encourages dividing practices closely linked to patterns of domination and the unequal distribution of resources. As institutions have a direct effect on the way in which newcomers are perceived (Reitz 1988, 118), community health centre direct their policies and programs toward inclusion (in order to avoid majority-minority competition and conflict) and addressing the root causes of ill health.

Refugees are not targeted as a priority group per se but only if they encounter circumstances such as poverty, isolation, cultural and linguistic alienation or other difficulties that impact on their physical and mental health and restrict their access and participation in the resources available to them. Special programs may be provided recognizing that refugees may be survivors of torture, that certain refugee communities have high rates of women as heads-of-families, that an entire refugee community may suffer from war trauma; that within families 
several members may have been killed, that many refugees have lost numerous years of education or employment due to long term residency in refugee camps or home country destabilization and that refugee youth, men and women are extremely vulnerable in resettlement.

\section{A "Realistic Utopian Vision" of Equality and Participation}

The $\mathrm{CHC}$ emphasis on integration and the potential for empowerment, especially for those who have largely been excluded from decision-making processes, reflects what Giddens (1990) has identified as a form of "radicalized modernity," i.e., social movements which emphasize achieving positive change in spheres such as political representation, the status of women and minorities. From the perspective of this paper, the way in which community health centres provide services and programs to newcomers is through a "dialogical" model. The dialogical model involves the making and implementing of policy through an extended process of communication between an agency and those affected by whatever issues are under consideration (Giddens 1987, 47). The CHC system is responsive to their clients, giving them greater control over health care decisions and providing them with accessible and culturally appropriate services. Through their emphasis on health promotion they go beyond traditional health care service delivery (heavily focused on illness and treatment) and attempt to understand the causes of illness, disability and determinants of health in practical ways such as employment, housing, literacy, migration and environment (Ministry of Health 1993b). CHCs encourage individuals, families and communities to take ownership of their own health and health care through more participation in addressing their particular health determinants including inequities and access issues. The emphasis is on what Beck, Giddens and Lash $(1993,23)$ refer to as sub-politics, the shaping of society from below in which groups hitherto uninvolved in implementing power, find a voice and a share in social arrangements.

\section{Notes}

1. For an overview of Canadian settlement policies see Lanphier and Lukomskyj 1994. By the mid-1980s, over 70 percent of immigrants entering Canada were from Asia, Africa, Latin/South America and Oceanic regions, and over one third did not know English or French (Boyd, de Vries, and Simkin 1987, Services such as orientation, housing, additional translators and interpreters, expanded language education, community development, individual life skills training and general assistance are delivered primarily through broad-based NGO settlement agencies.

2. In the 1994-1995 fiscal year, federal government estimates for settlement programs for immigrants totalled $\mathbf{\$ 2 7 1}$ million, of which $\$ 106$ million was to be directed towards language training, $\$ 51$ million to social assistance for immigrants, \$14 million to the immigrant settlement and adaptation fund, $\$ 2$ million to the host program, \$1 million to the International Organization for Migration and $\$ 90$ million direct funding to Quebec which controls its own immigrant settlement programs (Toronto Star, February 21, 1995, A9). To offset some of these costs, the federal government (in the 1995 February budget) imposed a $\$ 975$ universal levy fee on all adult immigrants and refugees (in addition to the existing processing fee of $\$ 500$ each for adults and $\$ 100$ for dependents). By comparison, the U.S. has a $\$ 1,644$ levy fee and Australia $\$ 4,575$, reflecting each country's level of language training and settlement services (Toronto Star, February 28, 1995, A9).

3. Community Health Centres (CHCs) are organizations funded by the Ontario Ministry of Health. They are sponsored and managed by incorporated non-profit community boards which must involve members of the community. All staff positions, including physicians, are salaried. Employees are responsible to the CHC's community board. The sponsoring of $\mathrm{CHCs}$ by community-based organizations emphasizes consumer and community empowerment through grass roots health promotions initiatives and community development strategies (Ministry of Health 1993a). As of February 1995, fifty-six Community Health Centres were located throughout Ontario, twenty-four in Toronto, six in Ottawa and twenty-six elsewhere (Ministry of Health 1993b). A complete list of all
CHCs in Ontario and a list of the numerous programs they provide is available from the Association of Ontario Health Centres, 5233 Dundas Street West, Suite 102, Etobicoke, Ontario, M9B 1 A6.

\section{Bibliography}

ARA Consulting Group Inc. 1992 (October). "Final Report: Evaluability Assessment of Ontario's Community Health Centre Program." Evaluation Project Group, Strategic Planning and Evaluation Project, Community Health Centre Program.

Beck, Ulrich, Anthony Giddens, and Scott Lash. 1994. Reflexive Modernization. Cambridge: Polity Press.

Bergin, Betty. 1993a (January). “Community Resource Centre Multicultural Planning Project: Summary of Phase I Findings." Multicultural Planning Committee of the Community Resource Centres of OttawaCarleton.

-1993b (August). "Guiding Principles for 'Getting Our Act Together' to Serve Our Changing Multicultural Community: The Workshop Follow-up Report." Multicultural Planning Committee of the Community Resource Centres of OttawaCárleton.

Boyd, Monica. 1990. "Immigrant Women: Language, Socioeconomic Inequalities and Policy Issues." In Ethnic Demography: Canadian Immigrant Racial and Cultural Variations, edited by S. Halli, F. Trovata, and L. Driedger. Ottawa: Carleton University Press.

- 1991 "Migrant Women and Integration Policies." Organization for Economic Cooperation and Development (OECD), Paris. Mimeo, 3-13.

Boyd, Monica, John de Vries, and Keith Simkin. 1994. "Language, Economic Status and Integration." In Immigration and Refugee Policy: Australia and Canada Compared, edited by Howard Adelman et al. Carlton, Toronto and Buffalo: University of Melbourne and University of Toronto Presses.

Equity in Strategic Health Planning Workshop Group (ESHPWG). 1994 (November). "Our Lives Our Communities Our Health!" Supported by the Ontario Ministry of Health, Metropolitan Toronto District Health Council.

Giddens, Anthony. 1987. Social Theory and Modern Sociology. Cambridge: Polity Press

1990. The Consequences of Modernity. Cambridge: Polity Press. 
Holland, Douglas A. 1993 (May). Somerset West Community Health Centre: Report on Community Profile, Clients and Services Input to Needs Assessment. Ottawa:SWCHC.

Lanphier, Michael, and Oleh Lukomskyj. 1994. "Settlement Policy in Australia and Canada." In Immigration and Refugee Policy: Australia and Canada Compared, edited by Howard Adelman et al. Carlton, Toronto and Buffalo: University of Melbourne and University of Toronto Presses.

Lanphier, Michael, Janet McLellan, and Edward Opoku-Dapaah. 1995. "Models for Newcomer Resettlement." Submitted in text proposal.

Lynam, Judith M. 1985. "Support Networks Developed by Immigrant Women." Social Science of Medicine 21, no. 3: 327-33.

McLellan, Janet. 1995. "Cambodian Refugees in Ontario: An Evaluation of the Resettlement and Adaptation." Toronto: Centre for Refugee Studies/York Lanes Press.

McLellan, Janet, and Anthony H. Richmond. 1994. "Multiculturalism in Crisis: A Postmodern Perspective on Canada." Ethnic and Racial Studies 17, no. 4: 662-83.

Ministry of Health. 1993a (June). "Community Health Centres in Ontario: A Picture of Health." Ontario Ministry of Health, Community Health Branch.

_. $1993 \mathrm{~b}$ (June). “Community Health Centre Program, Ontario Ministry of Health: Strategic Directions 1993/94-1996/97." Strategic Planning and Evaluation Project.

Opoku-Dapaah, Edward. 1993. "Directory of African Community Groups in Metropolitan Toronto." Toronto: Centre for Refugee Studies/York Lanes Press.

- 1995. "Somali Refugees in Toronto: A Profile." Toronto: Centre for Refugee Studies/York Lanes Press.

Reitz, Jeffrey. 1988. "The Institutional Structure of Immigration as a Determinant of Inter-racial Competition: A Comparison of Britain and Canada." International Migration Review 22, no. 1: 117-46.

Richmond, Anthony H. 1969. "Sociology of Migration in Industrial and Postindustrial Societies." In Sociological Studies 2: Migration, edited by J. Jackson. Cambridge: Cambridge University Press.

_. 1994. Global Apartheid: Refugees, Racism and the New World Order. Toronto, New York and Oxford: Oxford University Press.

Wong, D. 1989. "The Semantics of Migration." Sojourn 4, 2-7.

\title{
Neo-Liberal Strategies to Cut Costs in Settlement Services: Cost Recovery and Devolution
}

\author{
John Morris
}

\section{Abstract}

The author considers the range of settlement services funded by Citizenship and Immigration Canada (CIC) tracing the relative costs of settlement services in both Quebec and the rest of Canada. Government cost cutting and recovery strategies applied to settlement services are reviewed against an explanation of neo-liberalist ideology as it has been interpreted by the Federal government (1993-1997). Some of the arguments put forward against cost recovery are also reviewed.

\section{Précis}

L'auteur explore l'éventail des services d'intégration mis en place par Citoyenneté et Immigration Canada (CIC) en retraçant les coûts relatifs des services d'intégration au Québec et dans le reste $d u$ Canada. On passe en reouel'application des stratégies de compressions et de recouvrement budgétaires gouvernementales au cas spécifique du secteur des services d'intégration, ce qui permet de procéder à une explication de l'interprétation de l'idéologie néo-libérale à laquelle procéda le gouvernement fédéral (1993-1997). Certains des arguments mis de l'avant en matière de recouvrements de coûts sont aussi présentés.

\section{Neo-Liberalism}

The Canadian government started to follow neo-liberal economic policies in the mid-1980s. "Neo" preceding "liberal" means a new kind of liberalism. The old kind was the liberal school of economics that became famous after the publication of English economist Adam Smith's, The Wealth of Nations in 1776. Liberal economics advocated the

John Morris, PhD, is Assistant Professor of Geography, Nipissing University, North Bay. abolition of government intervention in economic matters. Free trade was seen as the best way for a nation's economy to develop; no restrictions on manufacturing, no barriers to commerce, and no tariffs. Such ideas were "liberal" in the sense of no controls. When applied to individuals it encouraged free enterprise and free competition without limits on profits or capital accumulation as would be argued for by varying stripes of socialists.

Economic liberalism prevailed in Canada and North America through the 1800 s and early 1900 s. With the Great Depression of the 1930s economist John Maynard Keynes was able to successfully challenge liberalism as the best policy for capitalists. He argued that full employment is necessary for capitalism to grow and it can be achieved only if governments intervene to increase employment. Through the post-World War II period North American economies grew quickly because of the age structure and export opportunities elsewhere. From the 1970s onward, however, with an older age structure and increased world competition, profits shrank inspiring the corporate elite to revive economic liberalism, making it thus new or neo-liberalism.

Four important concepts central to neo-liberalism are the following: cutting public expenditure for social services like education and health care; deregulation of government activities that might diminish profits; privatising government run businesses, for example utilities, hospitals; and eliminating the concept of "the public good" or "community" and replacing it with "individual responsibility." These are the concepts that are the basis for most governmental decision-making in Canada. 